\title{
中国・インド・フィリピン・北欧との感染症発生動向に関する共同研究
}

\author{
熟見 紋子，小林 宣道
}

札幌医科大学医学部衛生学講座

\section{Collaborative Research with Chinese, Indian, Filipino and North European Research Organizations on Infectious Disease Epidemics}

\author{
Ayako SUMI and Nobumichi KOBAYASHI \\ Department of Hygiene, Sapporo Medical University School of Medicine
}

\begin{abstract}
In this report, we present a short review of applications of time series analysis, which consists of spectral analysis based on the maximum entropy method in the frequency domain and the least squares method in the time domain, to the incidence data of infectious diseases. This report consists of three parts. First, we present our results obtained by collaborative research on infectious disease epidemics with Chinese, Indian, Filipino and North European research organizations. Second, we present the results obtained with the Japanese infectious disease surveillance data and the time series numerically generated from a mathematical model, called the susceptible/exposed/infectious/recovered (SEIR) model. Third, we present an application of the time series analysis to pathologic tissues to examine the usefulness of time series analysis for investigating the spatial pattern of pathologic tissue. It is anticipated that time series analysis will become a useful tool for investigating not only infectious disease surveillance data but also immunological and genetic tests.
\end{abstract}

Key words: time series analysis (時系列解析), infectious disease（感染症), surveillance（サーベイランス), temperature (気温), mathematical model (数学モデル)

1.はじめに

感染症の発生変動には, 宿主, 環境, そして病原体の 3 因子が相互に複雑に関与していると考兄らている (1)。そして，その 3 因子の時々刻々と変化する相互作 用を現象として観測可能なのが，感染症発生数時系列と いった実測時系列データである。これらの 3 因子の相互 作用を理解するために, 数理モデルが構築され, 実測デー タの時系列解析が行われてきた (2-4)。しかし, 数理モ デルに関する研究と実測データに関する研究が, 相互に 補いあって，発展してきたとは言い難い。その理由の一 つとして，これまでの時系列解析法が長いデータ長の時

受付 2016 年 12 月 14 日，受理 2017 年 1 月 14 日

Reprint requests to: Ayako SUMI

Department of Hygiene, Sapporo Medical University School of Medicine, S-1, W-17, Chuo-ku, Sapporo 060-8556, Japan

E-mail: sumi@sapmed.ac.jp
系列を前提にしており，多くても数百点の短い感染症の 実測データの時間的変動構造を精緻に抽出できず，従っ て, 数学モデルとの比較検討が十分に行われなかったこ とが挙げられる $(2,5) 。$

筆者は，これまで，中国，インド，フィリピン，デン マーク, そしてフィンランドと共同研究を行ら機会に恵 まれた。そして，短いデータ長の時系列からも，その変 動構造の特性を高精度に抽出する能力をもつ汎用時系列 解析法 “MemCalc”(6-9) を用いて，それらの国の感染症 の実測データの時系列解析を行い，実測データから有意 な情報を引き出すことに成功した。中国・インド・フィ リピンとの共同研究では, 各国がその時点で問題として 抱えている感染症を取り上げた。中国の場合は麻疹，結 核, 肝炎 ( A, B , C , E 型), そして手足口病 (10-13), インドの場合はロタウイルスなどを病原体とする下痢症 (14)，そしてフィリピンの場合はハリケーンの後に流行 するデング熱とレストスピラ症 $(15,16)$, デンマークと 
フィンランドでは, 20 世紀初頭から収集・蓄積されて きた感染症発生数時系列データ（17-19），そして日本で 1983 年からシステマティックに収集・蓄積されてきた 感染症サーベイランスデータ等々（20-28）であった。

これらの一連の解析結果から, 感染症発生の背後にあ る 3 因子（宿主, 環境, 病原体）の複雑な相互作用を明 らかにすることが出来たと考えている。例えば，感染症 によって，予防接種率の変化に起因する流行パターンが 観測され，気温や雨量といった気象変動と強い相関構造 を有していることが観測されるなど，時系列データに内 包されている情報が浮き彫りになった。

感染症サーベイランス事業の構築が，現在のところ発 展段階にある中国・インド・フィリピンでは，実測デー タは数十点しかない場合もあり, 解析結果の信頼性が問 われることになりかねない。こうした問題に対して，筆 者は，長期に渡って体系的に収集・蓄積された日本・デ ンマーク・フィンランドの感染症時系列データの高精度 の解析結果 (17-28) や感染症の数理モデル (13, 24, 29, 30）が生成する時系列の詳細な解析も行って, 中国・イ ンド・フィリピンの解析結果を理解する際の強固な客観 的判断材料を持ち得た。

本稿では，以上の中国・インド・フィリピンとの共同 研究で得られた結果を紹介寸るとともに, その共同研究 を支えた，日本・デンマーク・フィンランドの感染症時 系列データ，そして数理モデルを用いた研究成果を紹介 し, 感染症の流行対策への時系列解析の役割を考察する 材料としたい。

\section{2. 時系列解析とは (6-9)}

時系列解析の概要について，図 1 を用いて説明する。 図 $1 \mathrm{a}$ と $1 \mathrm{~b}$ は, 中国・武漢疾病予防センターで収集され
た，それぞれ結核の喀痰塗抹陽性抢よび喀痰塗抹陰性の 時系列である（10）。両時系列とも，一見したところ， 不規則であり，大きな違いがないが，時系列解析を実行 すると, 陽性の場合（図 1a'）は大きな流行が 1 年に 2 回, 春と夏に発生し，一方，陰性の場合（図 $1 b^{\prime}$ ） は, 1 年 に 1 回，春に発生することがわかった。

なぜ，このようなことがわかったのか。図 2 は喀痰塗 抹陰性の時系列データ（図 2a）を用いて，時系列解析 による処理のあらましを示したものである。まず，時系 列データ（図 $2 \mathrm{a} ）$ のスペクトル（図 $2 \mathrm{~b} ）$ を求めること によって，このデータに含まれる周期構造を，もしそれ があるならばすべて取り出す。この場合， 1 年および 6 カ月周期に，2つの顕著なスペクトルピークがある。こ れは，元のデータ（図 2a）が主にこの 2 つ周期から 構成されることを意味する。次に，これらの周期を元の 時系列にあてはめ (図 2c), 時系列中の周期成分を取り 出す。このように時系列解析によって，時系列に内包す る情報を取り出し，元の時系列を再構成することが可能 である。このことによって，時系列解析の最大の目標で ある，未来の予測值を定量的に評価することも可能とな る $(11,12,17,18,20,27)$ 。

\section{3. 海外との共同研究の成果}

\section{（1）デング熱・レプトスピラ症 [フィリピン]（15)}

図 3 左側に, フィリピン・マニラ市のサン・ラザロ病 院で収集されたデング熱（図 3a）とレプトスピラ症（図 3b）の発生報告数の時系列, そして気象データが上から 気温（図 3c），相対湿度（図 3d），そして雨量（図 3e） の順に示してある (15)。図 3 右側に, 時系列解析から 得られた，各時系列から抽出した 1 年周期を示す。上段 のデング熱の場合（図 3f)，気温（赤）のピークが 5 月

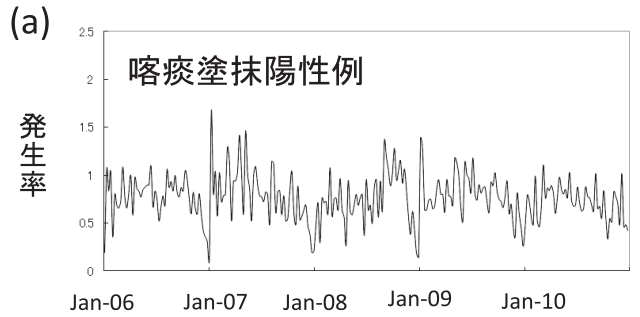

(b)

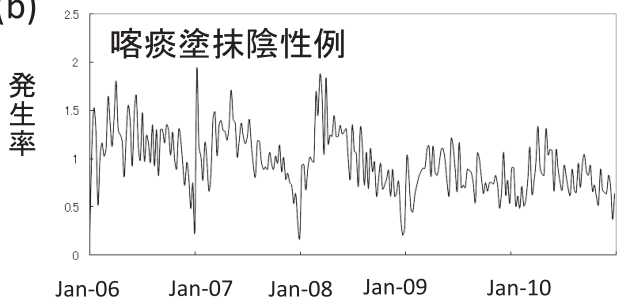

$\left(a^{\prime}\right)$

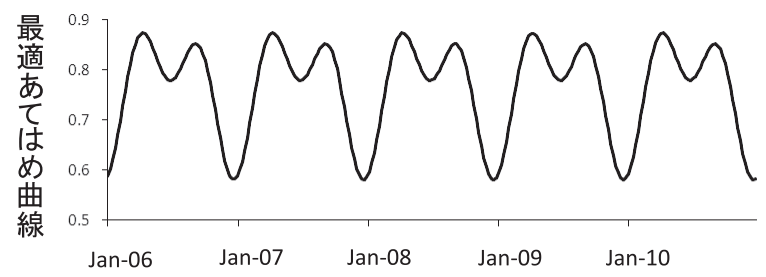

$\left(b^{\prime}\right)$

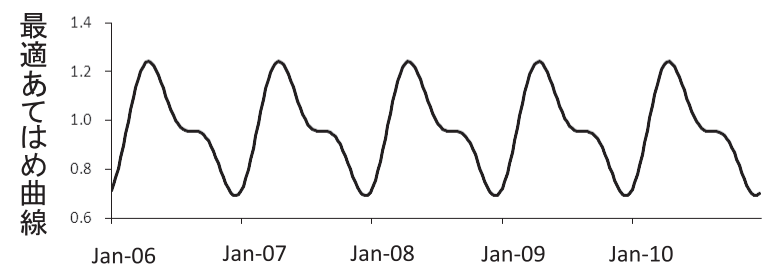

図 1 時系列と時系列の再構成。(a) と（b）中国・武漢市に抢ける結核サーベイランスで収集された，喀痰塗抹陽性・陰性患者数 の月毎報告数時系列データ（2006 年 1 月〜 2010 年 12 月)，（a'）と（b'） 1 年と 6 カ月周期を用いて計算したあてはめ曲線 [文献 (10) より改変]。 
(a) 時系列データ

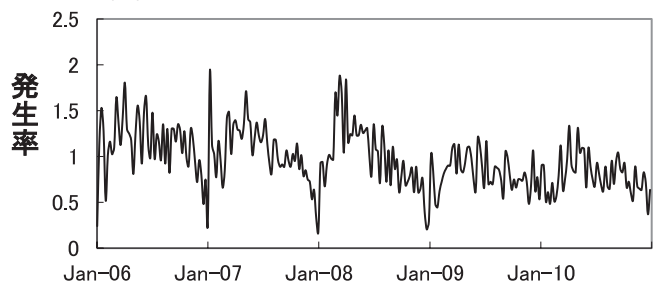

(c) あてはめ解析

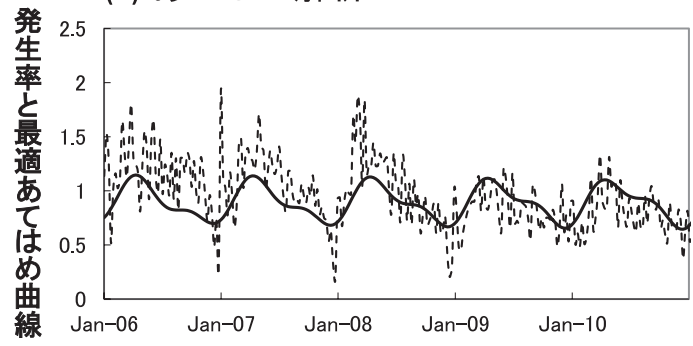

(b) スペクトル解析

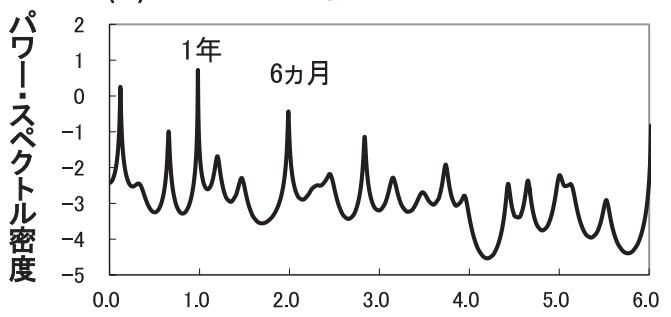

周波数

図 2 時系列解析の概要。（a）時系列データ，(b) そのパワー・スペクトル密度，(c) あてはめ曲線（実線）と原時系列データ（点線） [文献 (10)より改変］。

(a) デング熱入院患者数

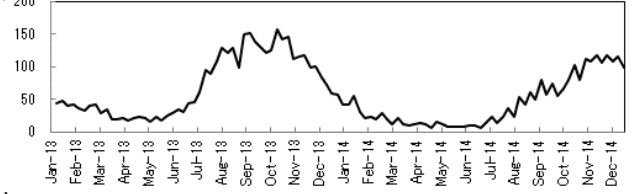

(b)

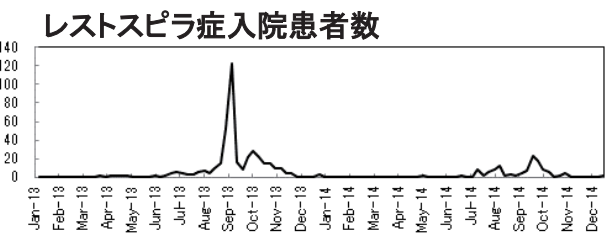

(c) 気温

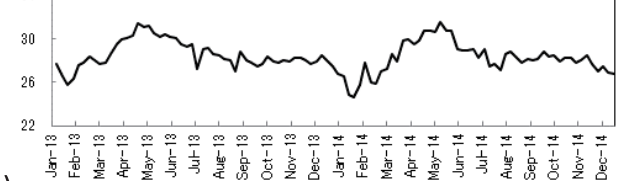

(d)

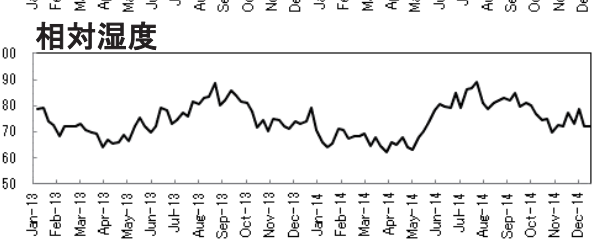

(e) 雨量

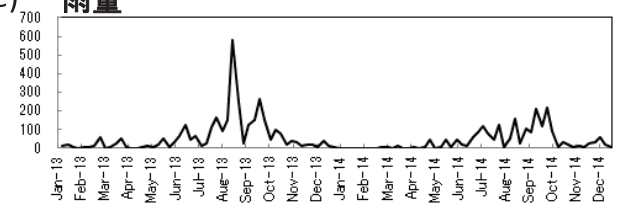

（f） デング熱の場合

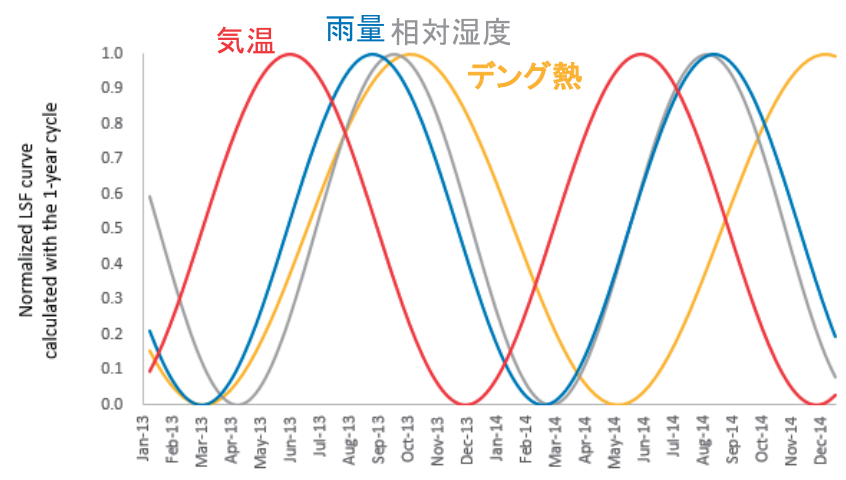

（g）レストスピラ症の場合

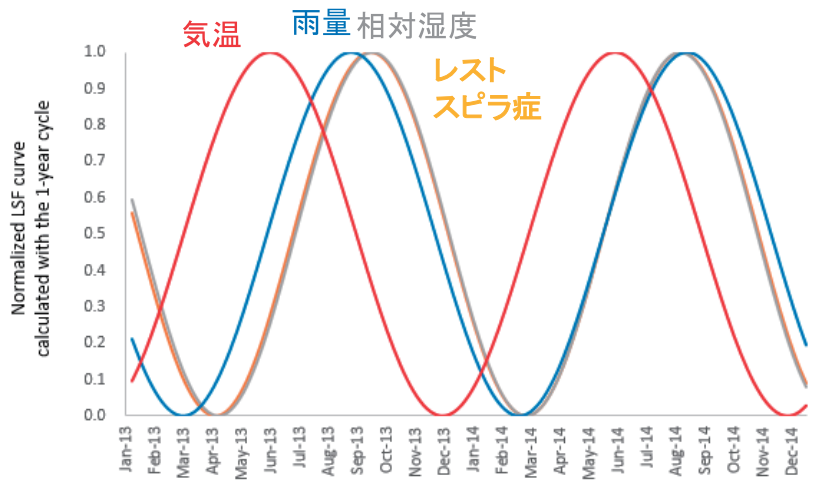

図 3 フィリピン・マニラ市内サン・ラザロ病院のデング熱・レストスピラ症患者数に対する時系列解析の結果。(a) デング熱入院 患者数，（b）レストスピラ症入院患者数，（c）気温，（d）相対湿度，（e）雨量，(f) デング熱入院患者数時系列データと気象データ に対する 1 年周期を用いて計算したあてはめ曲線，（g）レストスピラ症入院患者数時系列データと気象データに対する 1 年周期を用 いて計算したあてはめ曲線 [文献 (15) より改変]。 
に観測され，そのあとに雨量（青), 相対湿度 (グレー), そしてデング熱患者数 (黄) のピークが続く。この結果 は，フィリピンで観測されるモンスーンとデング熱の流 行の関係を示している。すなわち，気温（赤）が夏に上 昇し，海からの湿った風が大陸に吹きこんでモンスーン が吹き始めると雨（青）が増え, そして空気が湿って相 対湿度 (グレー) が上がる。その後, デング熱患者数（黄） のピークが観測される。レストスピラ症の場合（図 3g） は, 流行のピークがデング熱よりも 1 カ月早かった。こ れらの結果から，デング熱とレストスピラ症の患者数の 時間変化は，モンスーンによる 3 つの気象要因の一連の 時間変化と関係があることがわかる。筆者らは, 同じ手 法を用いて，インド・コルカタの国立コレラ腸管感染症 研究所で検出されたロタウイルスに関して，気象変動と の相関構造を定量的に示した（14）。

(2) コレラ [バングラデシュ ] (16)

バングラデシュのコレラの流行が繰り返し起こる現象 （図 4a）について，時系列解析を用いて調べた結果，コ レラの流行には 11 年周期（図 4b）があることがわかっ た (16)。この 11 年周期は，太陽黒点数の増減に観測さ れる周期であり, 太陽活動の指標として用いられている。
この 11 年周期を用いて，あてはめ曲線を計算した結果 を図 $4 \mathrm{c}$ に示す。同図によると, 太陽活動が活発になると， コレラの発生が減少する。つまり逆相関の関係にあるこ とがわかった。逆相関が起きる理由として，太陽活動が 活発になって太陽光が強くなると紫外線が増え，その紫 外線により海中の藻に付着するコレラ菌の増殖が抑制さ れる。一方，太陽光が弱くなって紫外線が減少するとコ レラ菌が増殖し, 雨季の洪水などによってコレラ菌がヒ トに接触してコレラ菌に感染する，といらメカニズムが 考えられた。

\section{（3）手足口病［中国］（12）}

手足口病は，起因病原体がエンテロウイルス $71 （ \mathrm{EV}$ A71）の場合に，中枢神経疾患を合併する割合が高いこ とが問題となって敃り，近年，日本，中国，台湾などの アジア太平洋地域で流行している。中国・武漢市に招け る手足口病（図 5a）は，1 年に 2 回のピークを示す年 2 峰性である。この年 2 峰性は, EV-A71 の検出数の時系 列 (図 5b) にも観測される。手足口病と EV-A71 のパワー・ スペクトル密度（それぞれ，図 5a'と5b'）には，両者 とも 1 年周期と 6 力月周期に対応する周波数に明瞭なス

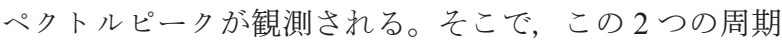

(a)

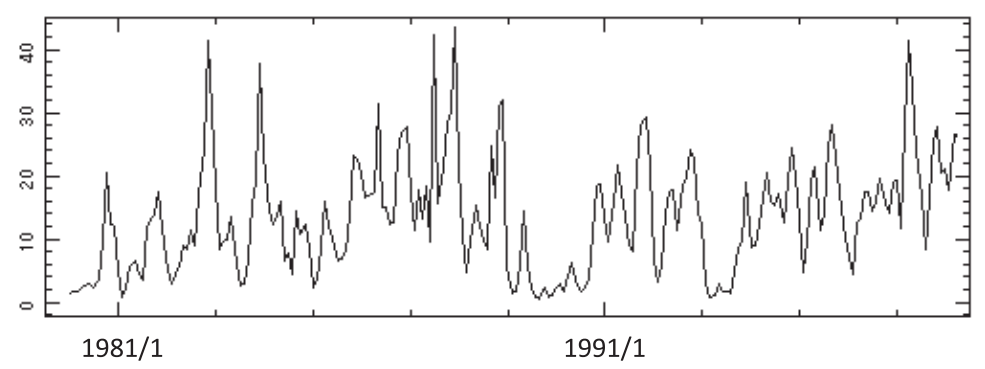

(b)

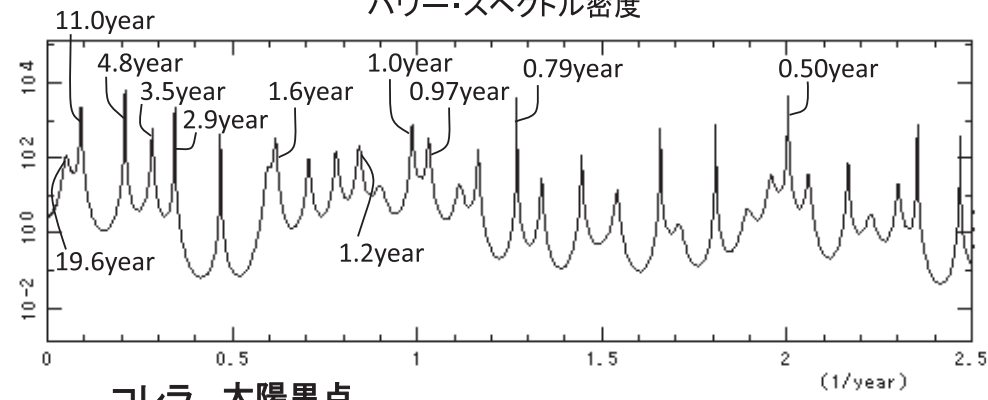

(c)

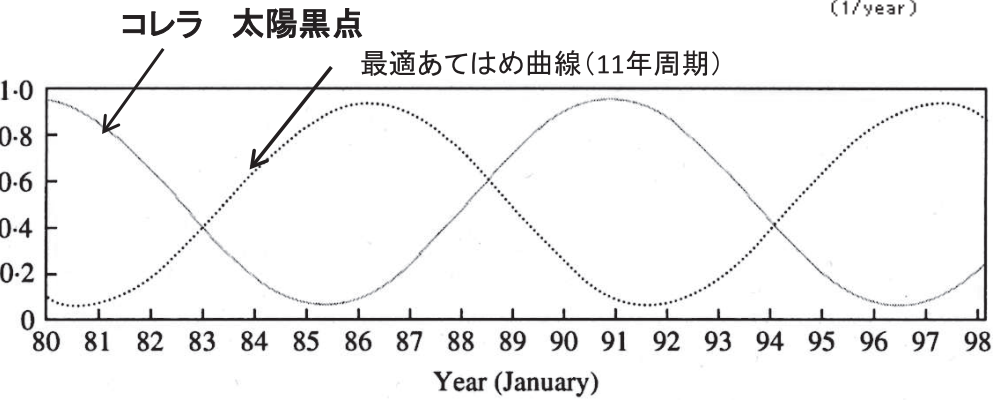

図 4 バングラデシュのコレラ発生数に対する時系列解析の結果。（a）コレラ発生数時系列データ, (b) そのパワー・スペクトル密度, (c) 1 年周期を用いて計算された時系列データ（a）特よび太陽黒点数時系列データに対するあてはめ曲線 [文献（16）より改变]。 

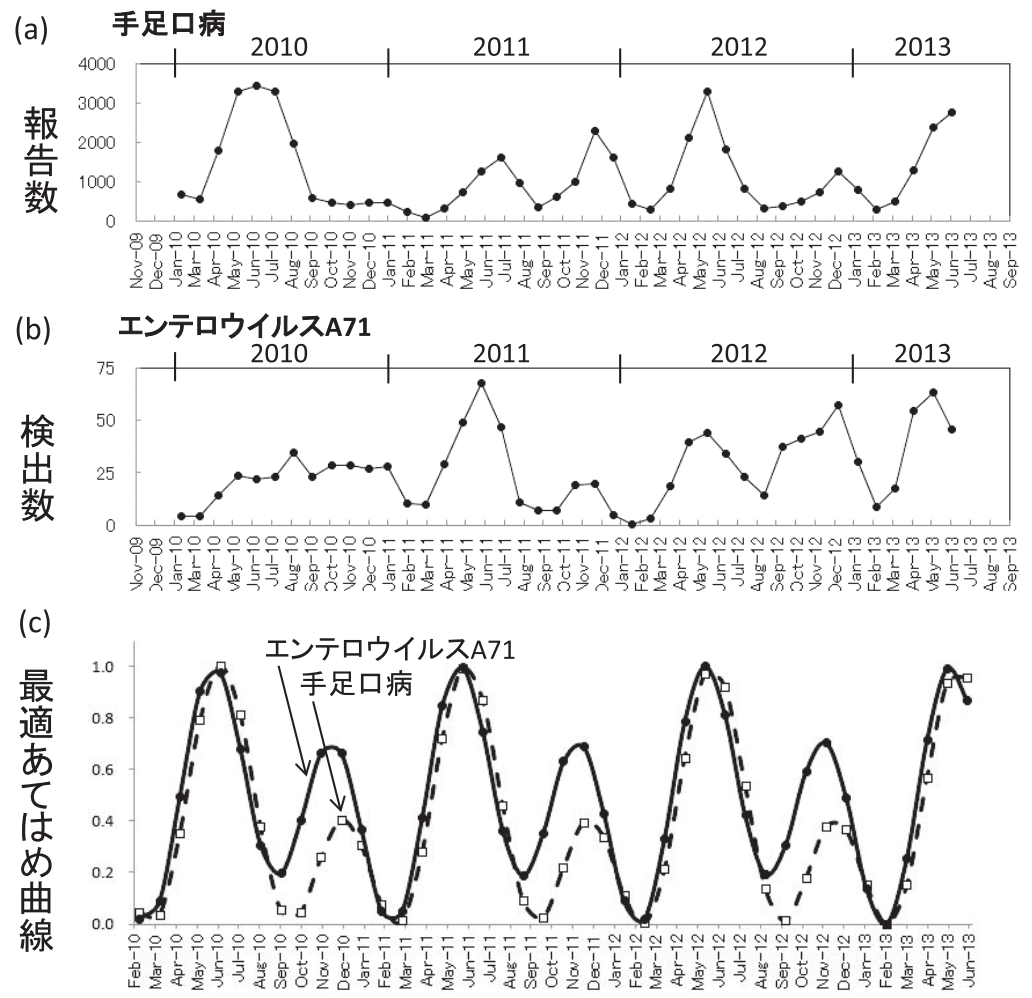

$\left(a^{\prime}\right)$

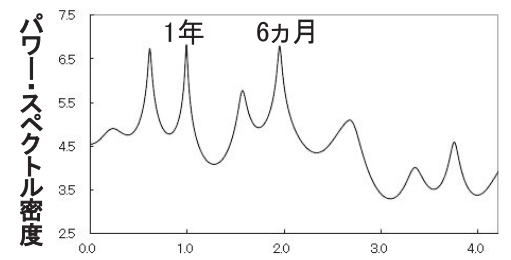

(b')

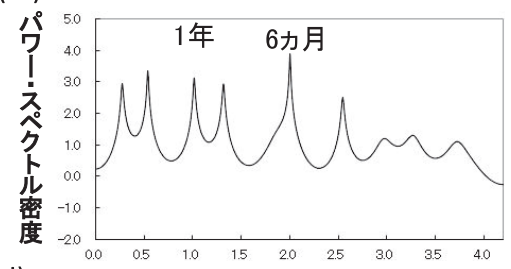

(d)

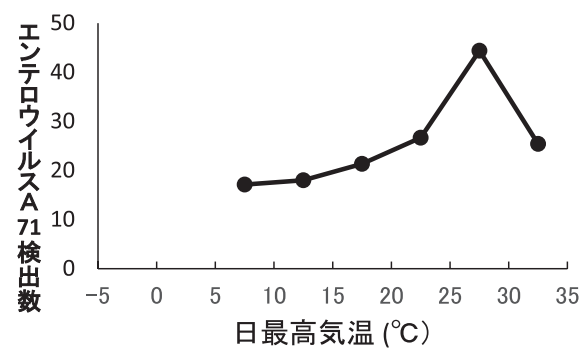

図 5 中国・武漢市の手足口病発生数とその病原体検出数に対する時系列解析の結果。（a）手足口病発生数時系列デ一タと（a'）そ のパワー・スペクトル密度（片対数表示），（b）エンテロウイルス A71 検出数時系列データと（b'）そのパワー・スペクトル密度（片 対数表示)，（c）時系列（a）と（b） と対する，1 年周期拈よび 6 カ月周期を用いて計算したあてはめ曲線，（d）エンテロウイルス A71 検出数の日最高気温に対するプロット[文献 (12) より改変］。

を用いて計算された最適あてはめ曲線（図 5c）は，手 足口病のピークは, EV-A71 とほぼ重なる。従って, 手 足口病の年 2 峰性の原因は EV-A71 に帰することが明ら かになった。

図 $5 \mathrm{~d}$ は, 手足口病患者からの EV-A71 検出数を最高 気温に対してプロットしたものである。検出数は, 最高 気温 $20^{\circ} \mathrm{C}$ 付近から検出数が増え, $30^{\circ} \mathrm{C}$ 付近でピークを 迎光た後, 発生数が減少するといら“逆 V 字型”を示す。 この結果は, 手足口病の病原体である EV-A71 が最高気 温に影響を受けていることを示唆するものであり, 手足 口病流行の予防・予測のためには, 最高気温に留意する ことが重要であることがわかった。

\section{4. 日本の感染症発生数 (率) 時系列データから 得られた結果}

\section{（1）水痘 (21)}

日本の水痘の流行パターンは，北日本と南日本で異な り, 北海道では年 2 峰性（図 6a)，そして沖縄では年 1 峰性（図 6b）である。その原因が気温である可能性に ついては，以前から指摘されていた（31）。そこで，全 国 47 都道府県の水痘発生率データと気象データ（気温, 相対湿度, 雨量) の時系列解析を行った。47 都道府県, すべての時系列のパワー・スペクトル密度には, 年 1 峰
性に対応する 1 年周期, そして年 2 峰性に対応する 1 年 周期と 6 力月周期に明瞭なスペクトルピークが観測され た（文献 21 の Figure 4)。そこで，時系列全体に対する 1 年周期と 6 力月周期の割合を評価するために， 1 年周 期と 6 力月周期の寄与率を計算した。寄与率とは，時系 列の振幅, 一時系列（図 $6 \mathrm{a}$ と $6 \mathrm{~b}$ ）の縦軸に相当するも ので, ここでは水痘発生率に相当する一, に対しての 1 年周期と 6 力月周期の振幅の割合に相当する。こうして 計算した, 各都道府県の 1 年周期と 6 力月周期の寄与率 を平均気温に対してプロットし，それぞれ図 $6 \mathrm{c}$ と図 $6 \mathrm{~d}$ に示す。 1 年周期の寄与率（図 6c） は平均気温が高くな るにしたがって大きくなる傾向があった。一方，6力月 周期の寄与率 (図 6d) は, 平均気温が高くなるにしたがっ て小さくなる傾向があった。この結果は, “平均気温が 高くなるに従って，年 1 峰性が出現し，年 2 峰性が消失 する”ことに対応し，水痘データ（図 6a と 6b）で視覚 的に観測された，“北海道で明瞭に観測された年 2 峰性 が，南下するに従って不明膫になり，沖縄では年 1 峰性 となる”という現象が気温に起因することを定量的に裏 付けたものである。

\section{(2) 結核 (22)}

結核流行の要因は，これまで年齢・性・気象・経済状 態の観点から説明されてきた。その中で年齢は，WHO 
(a) 年2峰性 (例) 北海道

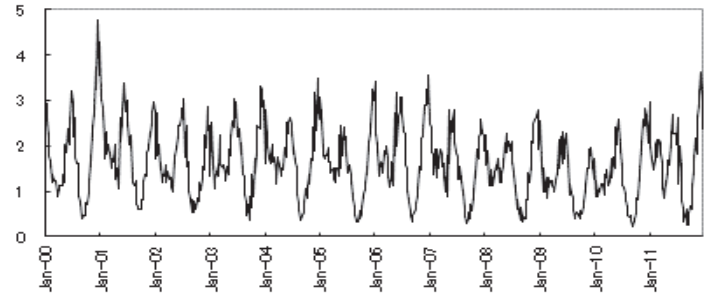

(b) 年1峰性 (例) 沖縄

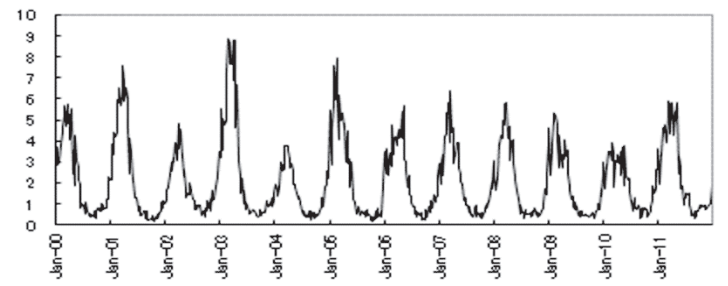

(c)

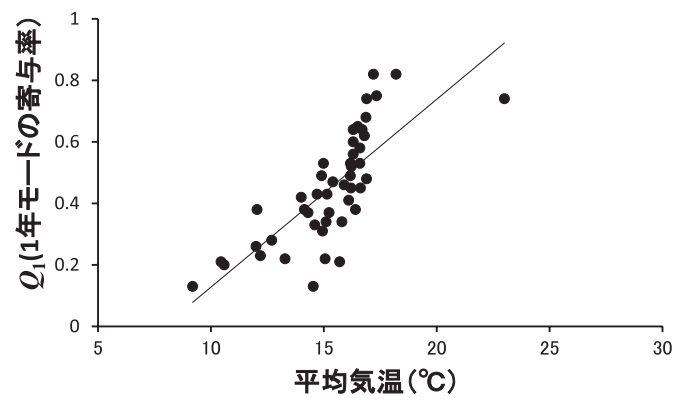

(d)

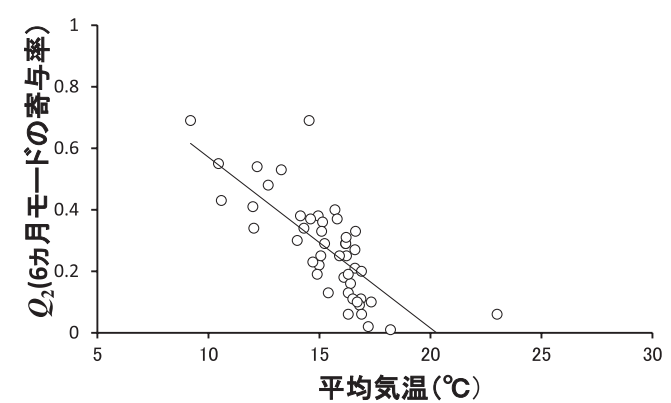

図 6 日本の 47 都道府県における水痘発生率の時系列解析の結果。（a）水痘発生率時系列データの年 2 峰性の例（北海道），(b) 水 痘発生率時系列データの年 1 峰性の例（沖縄），(c) 1 年モードの寄与率 $\left(Q_{1}\right)$ の日平均気温に対するプロット，(d) 6 カモードの 寄与率 $\left(Q_{2}\right)$ の日平均気温に対するプロット [文献 $(21)$ より改変 $]$ 。

が 2012 年から特に注目している結核流行の要因である。 そこで，日本で 1998 年から収集されている年齢階層別 (10 歳刻夕)の活動性結核新登録患者数の月毎データ（図 7 左側）の時系列解析を行った。各年噛階層別時系列の パワー・スペクトル密度には， 1 年周期に明瞭なスペク トルピークが観測された（文献 22 の Figure 4)。水痘 (本章 (1)）の場合と同様に 1 年周期の寄与率を計算し, 図 7 右側の結果を得た。同図によると，10-39歳と70 歳以上の場合において, 1 年周期の寄与率が他の年齢階 層に比べて大きい。この理由として，10-39 歳の場合は， 患者発生の報告は都会に多く（32），これは冬の時期に， 比較的換気の悪い満員の公共交通機関などで集団感染が 発生し（33），潜伏期間を経て春に患者数が増えると考 えた。一方, 70 歳以上の場合に 1 年周期の寄与率が大 きい（図 7 右側）といら結果は，ヒトの免疫力は季節に よって変化するといら報告（34）に基づいて説明できる。 70 歳以上の場合は，結核のハイリスク人口集団である だけでなく，低い気温に弱い（35）ため，冬の低温によっ て免疫力が弱くなることによって結核に感染し, 潜伏期 間を経て春に患者数が増加すると考兄られる。

\section{5. 数理モデルと麻疹}

\section{(1) 3D スペクトルアレイ $(13,23)$}

これまで紹介した感染症の実測データから得られた結 果は, 感染症の数理モデルから生成された時系列と, そ
の数理モデルが対象としている麻疹のサーベイランス データの時系列解析を通して得られた結果によって基礎 づけられる $(23,24,27) 。$

感染症の発生変動には, 多くの場合, 周期性が観測さ れる。感染症の数理モデルに関する研究で広く用いられ てきた、ニューヨーク市に打けるワクチン導入以前の麻 疹発生数の時系列データ（図 8a）では，1945 年以降に 小さい流行と大きい流行を交互に繰り返す 2 年周期が観 測され，1945 年以前にはこの 2 年周期から外れる不規 則変動が観測される。感染症の数理モデルでは, この不 規則変動が，測定䛊差などの雑音によるものなのか，あ るいは人口集団内での感染症の流行の背後に存在するダ イナミクス (力学系) によるものなのかに関心が集まっ た（36）。1980 年代に，Aron \& Shwartz(37) は，観測さ れる不規則変動が, 感染症発生変動の数理モデルとして 有名な, SEIR (susceptibles/exposed/infectives/recovered) モ デルから生成された時系列（図 8b）によって，良く説 明され，雑音によるものではないと報告した。完全に決 定論的な方程式によって記述される SEIR モデルによっ て生久出される不規則変動（図 8b）は，その系に内在 して発生するものであり，外部から雑音が付加されたた めに起こるものではない。このよらな不規則変動は決定 論的カオスと呼ばれ，麻疹発生はカオス過程であること が推測された。これは, 図 $8 \mathrm{e}$ に示す麻疹発生数時系列 の $3 \mathrm{D}$ スペクトルアレイに観測される 2 年周期がゆらぎ を伴っているといら振舞いに見られる。この 2 年周期の 
(a)

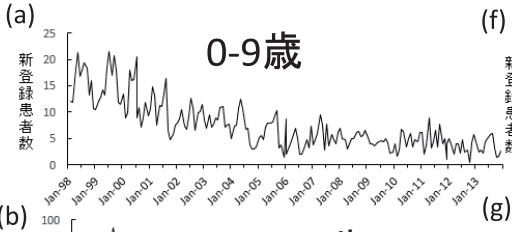

(b)

(f)

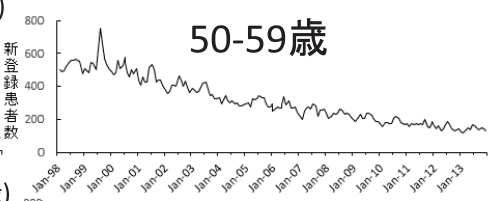

(j)

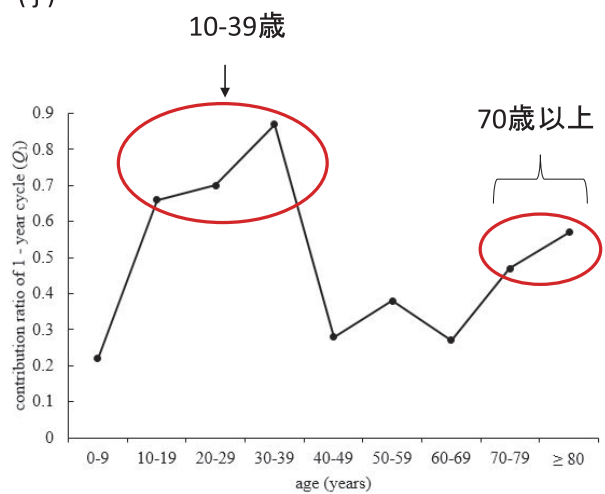
age (years) (d)

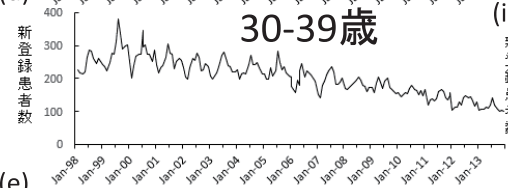

(e)
60-69歳

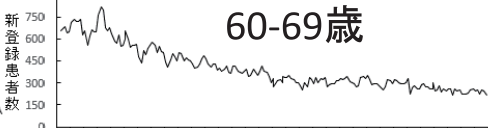

$70-79$ 歳

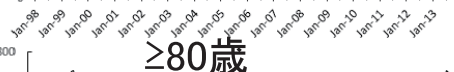

辋委

$$
\text { 40-49歳 }
$$

की

time (year)

図 7 日本の結核サーベイランスデータ（年齢階層別）の時系列解析の結果。（左側， $\mathrm{a}-\mathrm{i} ）$ 年齢階層別（10 歳刻み）の新登録患者数 時系列データ，（右側，j）年齢階層別の 1 年周期の寄与率 [文献 $(22)$ より改変］。

(a) ニューヨーク市の麻疹発生数の実測データ

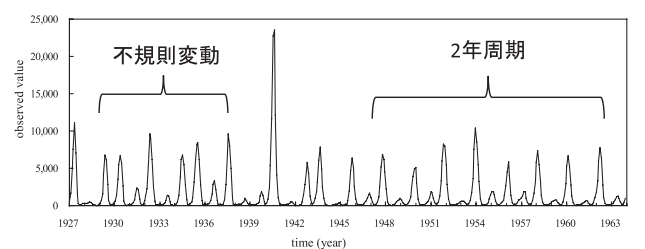

(b) SEIRモデルによって生成されたカオス時系列

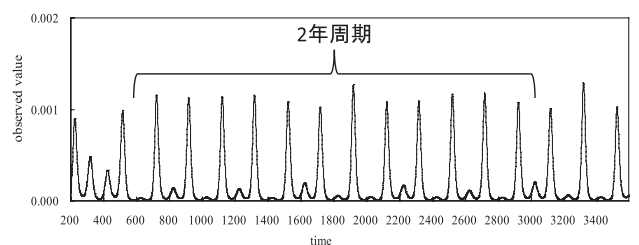

(c) 周期的時系列の場合

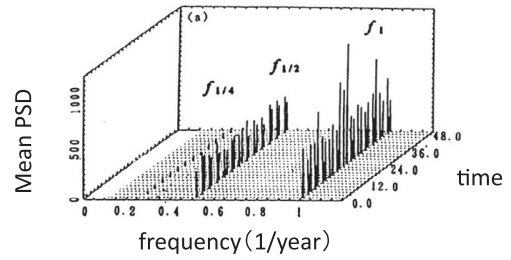

(d) カオス時系列の場合

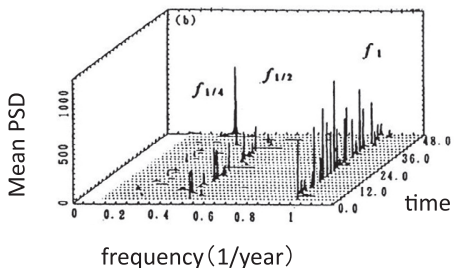

(e) 実測データの場合

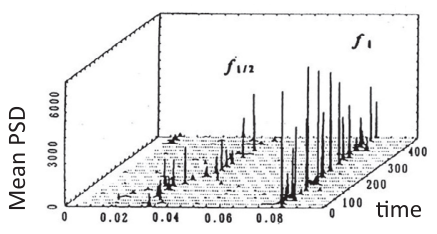

frequency (1/year)

図 8 感染症の数理モデルによって生成された時系列の解析結果。（a）ニューヨーク市の麻疹発生数時系列，（b） SEIR モデルから 生成されたカオス時系列，（c）SEIR モデルの周期的時系列から計算された $3 \mathrm{D}$ スペクトルアレイ，(d) SEIR モデルのカオス時系列 から計算された $3 \mathrm{D}$ スペクトルアレイ，（e）ニューヨーク市の麻疹発生数の時系列から計算された $3 \mathrm{D}$ スペクトルアレイ［文献（23） より改変]。

振舞いは, 図 8d に示す SEIR モデルによるカオス時系 列の 3D スペクトルアレイと酷似して抢り, 図 8c に示 す SEIR モデルによる周期的時系列の場合には観測され ない。このことから, 非線形力学過程としての麻疹発生 は，カオス過程であることが推測される。筆者による， 麻疹発生数変動のカオス性の詳細検証については, 文献 23 を参照されたい。
図 9a は, 中国・武漢市の麻疹発生数時系列の 3D ス ペクトルアレイの結果（13）であり, 周期構造が時々刻々 と変化していることがわかる。図 $9 b$ は，2 年よりも長 い周期をプロットしたものである。興味深いのは，この 長い周期の時々刻々とした変化が，武漢市で起きた社会 的な出来事と呼応していることである。集団予防接種が 導入される 1966 年以前は, 流行が 2 年周期で起きてい 
るが，導入以後は 2 年周期よりも長くなっている。こ の, 予防接種率 $\rightarrow$ 高, 流行周期 $\rightarrow$ 長といら関係は, 数理 モデルから予測されていることである（38-40）。この関 係は, 1978 年に武漢市の行政区域の変更によって予防 接種率が下がり (予防接種率 $\rightarrow$ 低), 流行周期が再び短 くなる（流行周期 $\rightarrow$ 短）ことからも観測される。その 後, 予防接種拡大プログラム (EPI), コールドチェーン の整備などの麻疹発生の予防対策を反映して, 流行周期 は㧪よそ 2 年を維持し, 2000 年に MMRワクチンの導 入によって予防接種率が急速に高くなると同時に, 流行 周期は約 4 年と再び長くなった。この, 予防接種率 $\rightarrow$ 高, 流行周期 $\rightarrow$ 長といら関係は, 日本の場合でも明膫に 観測された $(24)$ 。このよらに感染症の時系列の周期構 造は時々刻々と変化して扣り, 麻疹データの時系列解 析の結果によって, 麻疹予防対策の歴史が麻疹流行周 期に影響を及ぼすことを浮き彫りにするといらことは 非常に興味深い。

\section{（2）デンマークの麻疹発生数時系列データと指数スペ} クトル (19)

“指数スペクトル”は，カオス・モデルで有名なロー レンツ, ダフィング, レスラー・モデルによって生成さ れる時系列データや, 太陽黒点数や血圧脈圧波といった, その現象の背後のメカニズムが非線型ダイナミクスで説 明されている時系列データに打いても確認されて扣り $(7,29,30)$ ，また，多くの理論的拈よび実験的研究につ
いてレビューされている(41)。筆者は, この指数スペ クトルを日本はもとより，デンマーク，イギリス，アメ リカの麻疹発生数時系列データのスペクトルで確認した (19，27）。デンマークに関しては，20世紀初頭から地域 別に収集・蓄積された実測データ（図 10 左）を用いて 時系列解析を行った。図 10 左には, 9 つの地域のらち, 例として，シェラン島（首都コペンハーゲンが位置する 島）とボーンホルム島のデータとスペクトル解析の結果 を示す。これら 2 例を含む 9 つ地域のスペクトル解析 の結果，スペクトルの指数特性の傾きの值と人口集団の スケールとの間に，顕著な相関を観測した（図 10 右）。 感染症の流行が繰り返し発生するか否かは人口サイズに 依存するといら条件 (42) を前提として，この「人口 $\rightarrow$

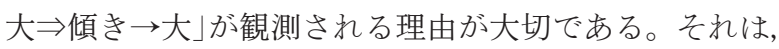
「人口増に伴い, 非線形効果による長周期の集積の介入 により，低周波数領域のパワー值が増大し，同時に偶発 的に計数されるノイズ成分の現象により, 高周波数領域 のパワー值が増大しない」ためでる。すなわち，「人口 増は，構成要素の相互作用を多様・多重化するため, 非 線形性を本質的なものとする。次いで空間的広がりを大 きくすることから，長距離相関が発生し，それは長時間 伝播現象を作り出す」(43)。デンマークのデータから得 られた結果は，イギリス扣よびアメリカ合衆国の場合に も確認された（図 10 右）。この結果は, 「人口サイズが 感染症発生変動の支配的要因になる」といらことを明ら かにする結果として重要であると考える。 (a)

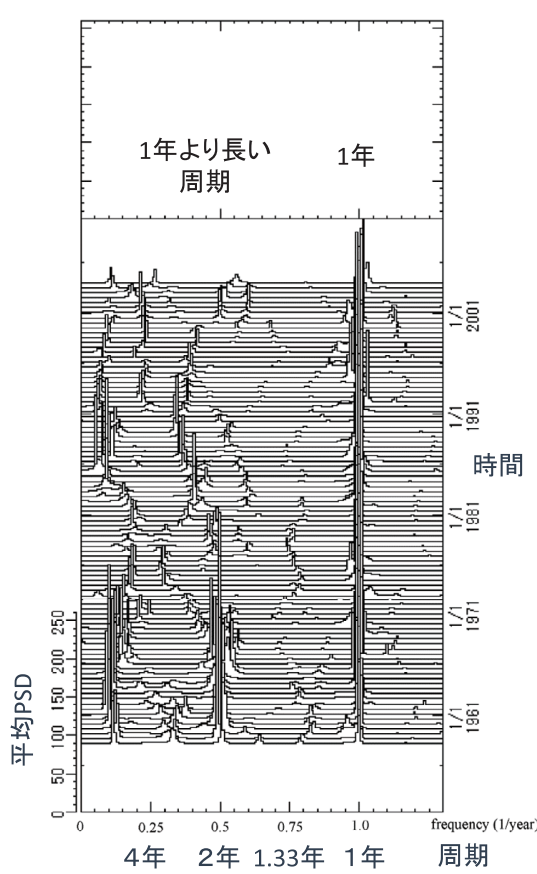

(b)

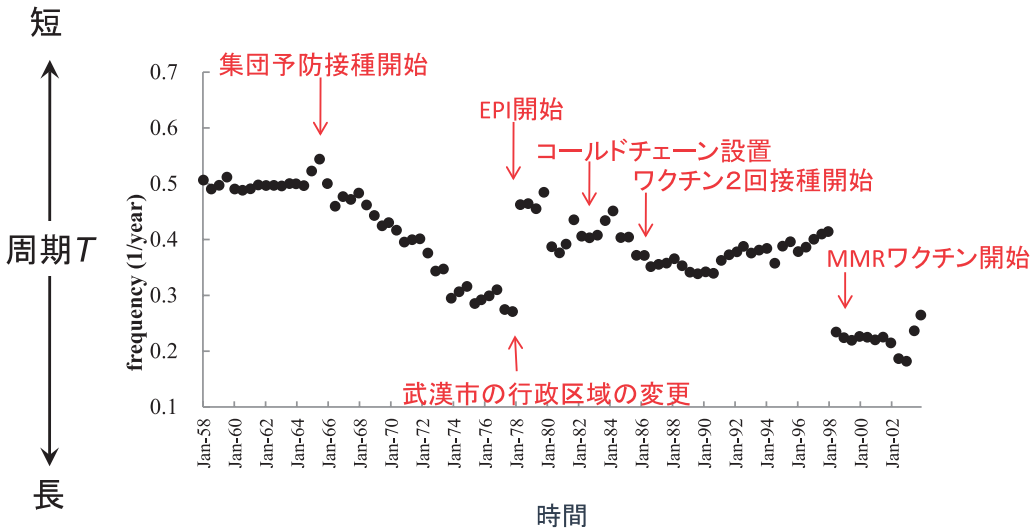

図 9 中国・武漢市の麻疹発生数に対する時系列解析の結果。（a）3D スペクトル解析（周波数領域 $f<1.25$ ), (b) 左図（a）の周波 数領域 $f<0.7$ で検出される, 最も支配的な（すなわち， パワー值の大きい）スペクトルピークが検出される周波数の時間変動 [文献 (13) より改変]。 
(a)シェラン島

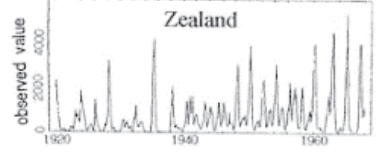

(b)ボーンホルム島

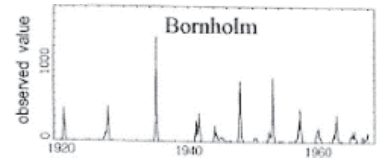

(a')

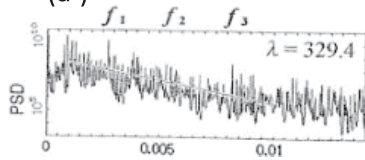

(b')

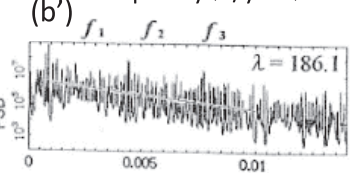

frequency (1/year)

(c)

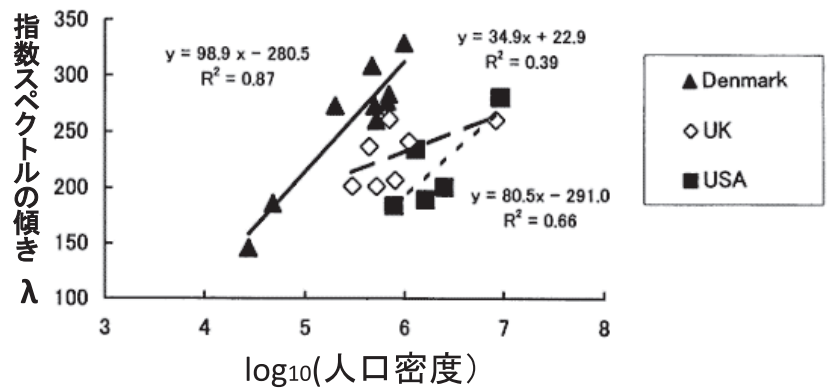

図 10 デンマークの麻疹発生数（1920 年〜 1967 年）とそのスペクトル解析の結果。（a）シェラン島（首都コペンハーゲンのある, デンマークで一番大きい島) のデータと（a'）そのパワー・スペクトル密度，(b) ボーンホルム島のデータと（b'）そのパワー・ス ペクトル密度，（c）人口スケールと指数スペクトルの傾きの相関関係［文献（19）より改変］。指数スペクトルとは，パワー・スペク

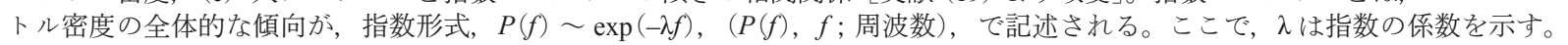

(a) 正常組織切片 (b) 正常モデル
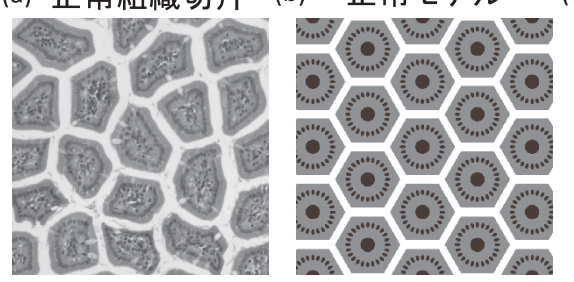

(c) 肥大モデル

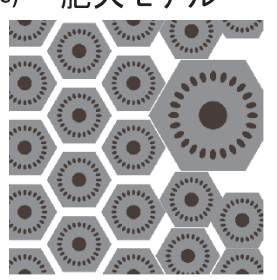

(d) 欠失モデル (e)

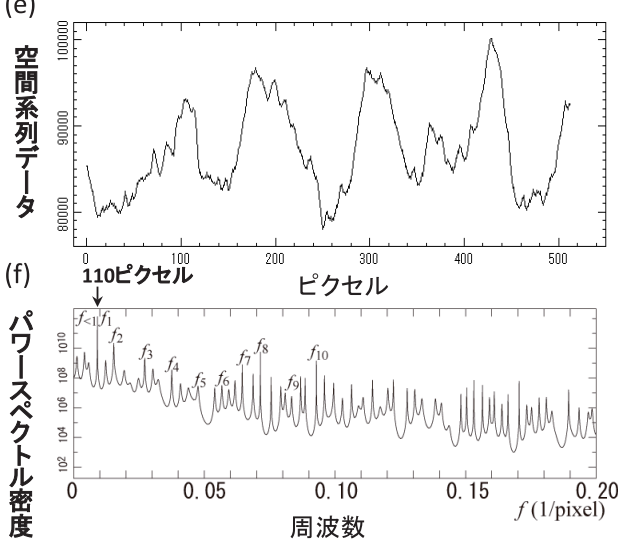

(g)

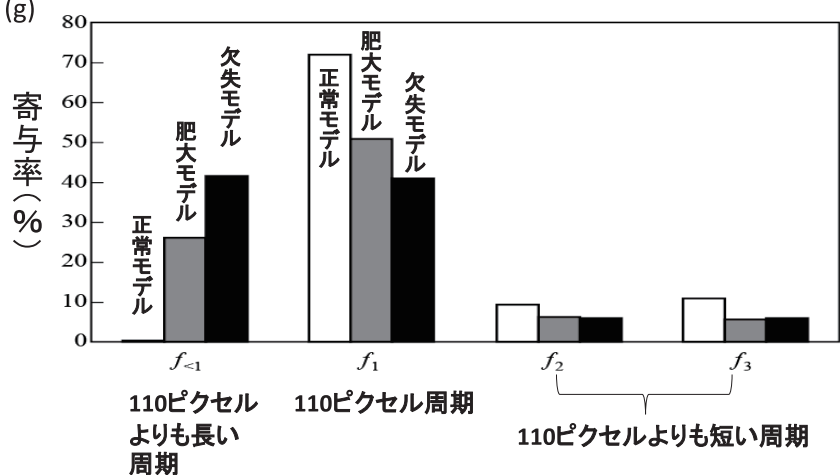

図 11 ICR マウス小腸の病理組織のモデルと，その空間系列データの時系列解析の結果。（a） ICR マウス小腸の病理組織，(b) 正 常モデル，(c) 肥大モデル，（d）欠失モデル，（e）（a）から得た空間配列データ，（f）（d）のパワー・スペクトル密度，（g）スペク トル解析から得られた寄与率 [文献 (44) より改変]。

\section{6. 更なる可能性 \\ 一時系列解析の空間系列データへの適用一 (44)}

本時系列解析法は，時系列データのみならず，空間系 列データに適用することができる。ここでは，マウスの 小腸組織を用いた，定量的病理学診断法としての時系列 解析の有用性の検討結果 (44) を示す。図 11a はマウス 小腸の正常組織切片から得られたグレ一画像である (512 $\times 512$ ピクセル, 512 ピクセルは $337 \mu \mathrm{m}$ に相当)。正常 組織の二次元モデル（図 11b）では，絨毛が六角形，上 皮細胞の核が円状に並ぶ 24 個の楕円，そして内皮細胞 と間質細胞の核が絨毛（六角形）の中央にある円で描か れている。更に, 二種類の二次元疾患モデル画像を構築
した；一つは腫瘍初期などで見られる絨毛構造の肥大を 伴ったもの（図 11c)，一つは潰瘍などで見られる䋐毛の 欠失を伴ったもの（図 11d）。実際の正常組織（図 11a）, 正常モデル（図 11b)，そして二つの疾患モデル（図 11c と 11d）から空間系列データを得て，スペクトル解析を 行った。例として実際の正常組織の空間系列データを

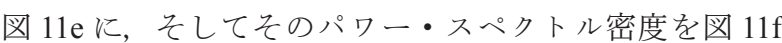
に示す。パワー・スペクトル密度（図 11f）では，最も 卓越したスペクトルピークが，䄉毛の大きさに対応する 110 ピクセル周期に観測された。正常モデルおよび疾患 モデルのスペクトル解析結果でも, 実際の正常組織の場 合と同様に，扣よそ 110 ピクセル周期に卓越したスペク トルピークが観測された（文献 44 の Figure 4)。ここで, 
110 ピクセル周期と, それよりも長い周期と短い周期の 寄与率を計算した結果を図 $11 \mathrm{~g}$ に示す（寄与率の意味に ついては，本稿 “第 4 章（1）水痘”を参照されたい)。 図 $11 \mathrm{~g}$ によると, 正常モデルと二つの疾患モデルのいず れの場合も，110 ピクセル周期の寄与率が大きい。更に 興味深い結果は, 110 ピクセルよりも長い周期の寄与率 が，疾患モデルの場合は肥大モデル $25.9 \%$, 欠失モデル の $41.7 \%$ と, 正常モデルの場合の $0.31 \%$ より大きい。 この結果は, 疾患モデル（図 $11 \mathrm{c} と 11 \mathrm{~d}$ ）の空間系列デー タの不規則性によるものであり, 疾患を持つ組織の, 規 則的で正常なパターンからの逸脱，すなわち構造異型と 関連づけられることを示唆するものである。

\section{7. おわりに}

感染症の発生変動には, 宿主, 環境 (特に気象条件), そ して病原体の 3 因子が相互に複雑に関与していると考兄 られている。本稿においては, 感染症発生変動と環境因子 の中の気象との関係を明らかにした一連の結果を紹介し た。それらの結果は, 第3 章に拈いて, 主として海外との 共同研究に基づいて得られた，デング熱とレストスピラ 症の気象との関連, コレラと太陽黒点の関連, 手足口病と その病原体の気象との関連, そして第 4 章に拈いて, 日 本の感染症について得られた, 水痘と気象の関連である。

日本は南北に長い国で, 気象が多様であるため, 感染症 と気象の相関を調べるためには非常に興味深いフィール ドである。日本には厚生労働省による感染症サーベイラ ンスデータ, そして気象庁による気象データが存在する ので, 今後もこれらを一層活用することによって, 本稿で 紹介したように, 海外の比較的短いデータ長である感染 症の発生変動の研究に役立て, 今日的課題である感染症 流行に対する気象現象の影響の解明に一役を担いたい。

そして今後, 本時系列解析の適用範囲をさらに広げ, 第 4 章で触れた，ヒトの免疫力の季節変化を調べるため に, 時系列解析を免疫学的検査結果に適用して行くこと も魅力的な研究課題であると思わ孙るそして第 6 章で 紹介したように, 本時系列解析法は空間系列データにも 適用可能であることから, 感染症病原体同定のための遺 伝子検査から得られる DNA 配列データにも適用可能で あると考えられる。こうして, 時系列解析は, 現在懸念 されているウイルスの変異などによる新興・再興感染症 の発生変動の振舞いを解明するとともに, 感染症発生の 予防にも役立つものと考光られる。

\section{謝辞}

本研究の一部は, JSPS 科研費, JP16K09061, JP25460769, JP25460769 の助成を受けて行われた。

利益相反なし

\section{文献}

(1) Begon M, Harper JL, Townsend CR. 生態学一個体 - 個体 群・群集の科学一. 京都: 京都大学学術出版会, 2003.

( 2 ) Anderson RM, May RM. Infectious Disease of HumansDynamics and Control-. London: Oxford University Press, 1991.

( 3 ) Keeling MJ, Rohani P. Modeling infectious diseases in humans and animals. New Jersey: Princeton University Press, 2008.

(4) May RM, McLean AR. Theoretical ecology (3rd Ed). London: Oxford University Press, 2007.

( 5 ) May RM. The chaotic rhythms of life. In: Hall N (ed), The new scientist guide to chaos. London: IPC Magazines New Scientist, 1991, 82-95.

（6）常盤野和男, 大友詔雄, 田中幸雄. 最大エントロピー 法による時系列解析一MemCalc の理論と実際一. 札 幌 : 北海道大学図書刊行会, 2002.

（７）細田嵯一 (監修), 笠貫 宏, 大友詔雄(編)。生体時 系列データ解析の新展開. 札幌 : 北海道大学図書刊行 会, 1996.

( 8 ) Saito K, Koyama A, Yoneyama K, Sawada Y, Ohtomo N (eds). A Recent Advance in Time Series Analysis by Maximum Entropy Method-Applications to Medical and Biological Sciences-. Sapporo: Hokkaido University Press, 1994.

（9）三宅浩次 (監修), 高橋延昭, 神山昭男, 大友詔雄 (編). 生物りズムの構造一MemCalcによる生物時系列デー 夕の解析一. 札幌 : 富士書院, 1992.

(10) Luo T, Sumi A, Zhou D, Kobayashi N, Mise K, Yu B, Kong D, Wang J, Duan Q. Seasonality of reported tuberculosis cases from 2006 to 2010 in Wuhan, China. Epidemiol Infect 2014;142:2036-2048.

(11) Sumi A, Luo T, Zhou D, Yu B, Kong D, Kobayashi N. Time-series analysis of hepatitis A, B, C and E infections in a large Chinese city: application to prediction analysis. Epidemiol Infect 2013;141:905-915.

(12) Chen B, Sumi A, Toyoda S, Hu Q, Zhou D, Mise K, Zhao J, Kobayashi N. Time series analysis of reported cases of hand, foot, and mouth disease from 2010 to 2013 in Wuhan, China. BMC Infect Dis 2015;15:495-509.

(13) Luo T, Sumi A, Zhou D, Kamo K, Yu B, Zhao D, Mise K, Kobayashi N. Study on the effect of measles control programmes on periodic structures of disease epidemics in a large Chinese city. Epidemiol Infect 2011;139:257-264.

(14) Sumi A, Rajendran K, Ramamurthy T, Krishan T, Nair GB, Harigane K, Kobayashi N. Effect of temperature, relative humidity and rainfall on rotavirus infections in Kolkata, India. Epidemiol Infect 2013;141:1652-1661.

(15) Sumi A, Telan EFO, Chagan-Yasutan H, Piolo M, Hattori T, Kobayashi N. Effect of temperature, relative humidity and rainfall on dengue fever and leptospirosis infections in Manila, the Philippines. Epidemiol Infect 2017;145:78-86.

(16) Ohtomo K, Kobayashi N, Sumi A, Ohtomo N. Relationship of Cholera Incidence to El Ninõ and Solar Activity Elucidated by Time-Series Analysis. Epidemiol Infect 2010;138: 
99-107.

(17) Sumi A, Hemilä H, Mise K, Kobayashi N. Predicting the Incidence of Human Campylobacteriosis in Finland with Time Series Analysis. APMIS 2009;117:614-622.

(18) Sumi A, Ohtomo N, Tanaka Y, Sawamura S,Olsen LF, Kobayashi N. Prediction analysis for measles epidemics. Jpn J. Appl Phys 2003;42:7611-7620.

(19) Sumi A, Olsen LF, Ohtomo N, Tanaka Y, Sawamura S. Spectral study of measles epidemics: the dependence of spectral gradient on the population size of the community. Jpn J Appl Phys 2003;42:721-733.

(20) Sumi A, Kamo K. MEM spectral analysis for predicting influenza epidemics in Japan. Environ Health Prev Med 2012;17:98-108.

(21) Harigane K, Sumi A, Mise K, Kobayashi N. The role of temperature in reported chickenpox cases from 2000 to 2011 in Japan. Epidemiol Infect 2015;143:2666-2678.

(22) Kohei Y, Sumi A, Kobayashi N. Time-series analysis of monthly age-specific numbers of newly registered cases of active tuberculosis in Japan from 1998 to 2013. Epidemiol Infect 2016;144:2401-2414.

(23) Sumi A, Ohtomo N, Tanaka Y. Study on chaotic characteristics of incidence data of measles. Jpn J Appl Phys 1997; 36:7460-7472.

(24) Sumi A, Kamo K, Ohtomo N, Kobayashi N. Study of the effect of vaccination on periodic structures of measles epidemics in Japan. Microbiol Immunol 2007;51:805-814.

(25) Sumi A, Ohtomo N, Mise K, Kobayashi N. Time series analysis of incidence of influenza in Japan. J Epidemiol 2011;21:21-29.

(26) Sumi A. Time series analysis of surveillance data of infectious diseases in Japan. Hokkaido J Med Sci 1998;73:343363.

(27) Sumi A, Ohtomo N, Tanaka Y, Koyama A, Saito K. Comprehensive spectral analysis of time series data of recurrent epidemics. Jpn J Appl Phys 1997;36:1303-1318.

(28) Sumi A, Kobayashi N, Ohtomo N. Proportion of sporadic gastroenteritis cases caused by rotavirus, norovirus, adenovirus and bacteria in Japan from January 2000 to December 2003. Microbiol Immunol 2005;49:745-746.

(29) Ohtomo N, Sumi A, Tanaka Y, Tokiwano K, Terachi S. A Detailed Study of Power Spectral Density for Rossler System. J Phys Soc Jpn 1996;65:2811-2823.
(30) Ohtomo N, Tokiwano K, Tanaka Y, Sumi A, Terachi S, Konno H. Exponential Characteristics of Power Spectral Densities Caused by Chaotic Phenomena. J Phys Soc Jpn 1995;64:1104-1113.

（31）庄司 真, 角田 行, 石田名香雄. 気象之感染症流行 の相関について一宮城県の感染症サーベイランスを 中心にして一. 抗酸菌病研究所雑誌 1986;38:91-101.

（32）公益財団法人結核予防会 結核の統計 2012. 東京 : 公益財団法人結核予防会, 2012, 11 .

（33）星野斉之，内山和広，山内祐子．青中年期結核罹患率 の地域差に関する研究. 結核 2009;84:1-8.

(34) Bratescu A, Teodorescu M. Circannual variations in the B cell/T cell ratio in normal human peripheral blood. J Allergy Clin Immunol 1981;68:273-280.

（35）山元昭二，清水 明，内村和広，大森正子，安藤 満. 関東地区に打ける高齢者の菌陽性肺結核䍜患率の季 節変動と気象要因との関係. 日生気誌 2003;40:83-92.

(36) Baily NTJ. The Mathematical Theory of Infectious Diseases and Its Applications (2nd Ed). New York: Charles Griffin, 1975.

(37) Aron JL, Schwartz IB. Seasonality and period-doubling bifurcations in an epidemic model. J Theor Biol 1984;110: 665-679.

(38) Anderson RM, Grenfell BT. Oscillatory fluctuation in the incidence of infectious disease and the impact of vaccination: time series analysis. J Hyg-Cambridge 1984;93:587608 .

(39) Anderson RM, May RM. Directly transmitted infectious diseases: control by vaccination. Science 1982;215:10531060.

(40) Grenfell BT, Anderson RM. The estimation of age-related of infection from case notifications and serological data. J Hyg-Cambridge 1985;95:419-436.

(41) Istratov AA, Vyvenko OF. Exponential analysis in physical phenomena. Rev Sci Instrum 1999;70:1233-1257.

（42）重定南奈子. 侵入と伝播の数理生態学. 東京: 東京大 学出版会, 1992, 100-124.

(43) 大友詔雄. 身体の時系列解析. Therapeutic Research 1999;20:1405-1415.

(44) Mise K, Sumi A, Kobayashi N, Torigoe T, Ohtomo N. Spectral Analysis of Spatial Series Data of Pathologic Tissue: A Study on Small Intestine in ICR Mouse. Jpn J Appl Phys 2009;48:017001-1-017001-9. 